\title{
TRAP ATTRIBUTES INFLUENCING CAPTURE OF Diabrotica speciosa (COLEOPTERA: CHRYSOMELIDAE) ON COMMON BEAN FIELDS
} \author{
Fujimoto $^{3}$ \\ ${ }^{1}$ UEL/CCA - Depto. Agronomia, C.P. 6001-86051-970 - Londrina, PR - Brasil. \\ ${ }_{3}^{2} U E L / C C A$ - Programa de Pós-Graduação em Agronomia. \\ ${ }^{3}$ UEL/CCA - Graduandos em Agronomia. \\ *Corresponding author <mventura@uel.br>
}

Maurício Ursi Ventura ${ }^{*}$; Claudio Cezar Mariano Resta²; Daiane Heloísa Nunes³; Fabio

\begin{abstract}
Refinements in trap characteristics may improve ability to monitor and mass-trap beetles. Field assays were conducted in common bean fields to assess responses of Diabrotica speciosa (Germar) to some trap characteristics. Golden yellow plastic cups $(750 \mathrm{~mL})$ traps caught more $D$. speciosa females and males than did clear traps. Carrot slices in Petri dishes baited with Lagenaria vulagaris L. powder (cucurbitacin source $-0.28 \%$ ) caught more beetles than did dishes with carrot alone. Dispensers for the floral volatile attractant 1,4-dimethoxybenze were also compared. Rubber septa dispenser attracted more beetles than did control (dental wicks saturated with acetone). Captures on dental wick, starch matrix and feminine pad dispensers were intermediate and did not differ from those on rubber septa and unbaited controls. Perforated bottle traps $(2000 \mathrm{~mL})$, when baited with the floral attractant, caught more beetles than did window bottle traps (both traps contained L. vulgaris powder) in most assessments done from two to ten days after trap placement in the field. Traps with the insecticide carbaryl captured more beetles than did traps without it, 2-4 and 8-10 days after trap placement in the field, but not in the remaining periods (0-2, 4-6 and 6-8 days). Traps baited with 1,4-dimethoxybenzene captured more beetles than did the unbaited ones in all assessments (each other day from two to ten days after trap placement in the field). Finally, similar amounts of beetles were captured using plastic bottle traps $(2000 \mathrm{~mL})$ : perforated, window (both with cucurbitacin) and sticky (without cucurbitacin) traps, when were baited with the floral attractant.
\end{abstract}

Key words: attractant, feeding stimulant, semiochemical, integrated pest management

\section{ATRIBUTOS DA ARMADILHA INFLUENCIAM CAPTURA DE Diabrotica speciosa (COLEOPTERA: CHRYSOMELIDAE) EM FEIJOEIRO}

RESUMO: Refinamentos em caraterísticas de armadilhas podem incrementar sua habilidade para monitorar e capturar em massa os insetos. Experimentos foram conduzidos em lavoura de feijoeiro para verificar as respostas de Diabrotica speciosa (Germar) a algumas características de armadilhas. Armadilhas de copos plástico $(750 \mathrm{~mL})$ amarelo ouro capturaram mais fêmeas e machos de $D$. speciosa do que transparentes. Placas de Petri com pedaços de cenoura, com pó seco de purungo, Lagenaria vulgaris L. (fonte de cucurbitacina - 0,28\%) capturaram mais insetos do que placas com somente cenoura. Liberadores para o atraente floral 1,4dimetoxibenzeno foram também comparados. Liberador de septo de borracha atraiu mais insetos do que o controle (flocos dentais saturados com acetona). Capturas nos tratamentos com liberadores de floco dental, matriz borato e absorvente higiênico foram intermediárias mas não diferiram da testemunha e septo. Modelo de armadilha de garrafa $(2000 \mathrm{~mL})$ furada capturou mais insetos do que armadilha vazada ("janelas") (ambas contendo pó seco de purungo) na maioria das avaliações, dos dois até os dez dias após a instalação das armadilhas no campo. Armadilhas com inseticida carbaryl capturaram mais insetos do que armadilhas sem, nos intervalos de 2-4 e 9-10 dias após a instalação das armadilhas no campo. Nos períodos restantes (0-2, 46- e 6-8 dias), diferenças não foram detectadas. Armadilhas com 1,4-dimetoxibenzeno capturaram mais insetos do que armadilhas sem o volátil (avaliações a cada dois dias dos dois aos dez dias após a instalação no campo). Finalmente, quantidades similares de insetos foram capturadas usando armadilhas de garrafa pet (2000 mL): vazadas ("janelas"), furadas (ambas com cucurbitacina) e adesivas quando estas foram iscadas com o atraente floral.

Palavras-chave: atraente, estimulante alimentar, semioquímico, manejo integrado de pragas

Sci. Agric. (Piracicaba, Braz.), v.62, n.4, p.351-356, July/Aug. 2005 


\section{INTRODUCTION}

Extremely bitter cucurbitacins are toxic or repellent to non-adapted phytophagous arthropods (Costa \& Jones, 1971), but are powerful arrestants and phagostimulants for adult diabroticites (Diabrotica spp., Acalymma spp. and Aulacophora spp.) (Metcalf \& Metcalf, 1992). Cucurbitacin baits are being used in the corn rootworm areawide management program in NorthAmerican corn fields (Chandler \& Faust, 1998). Traps containing cucurbitacin from Lagenaria vulgaris L. (Cucurbitaceae) powder have been used successfully to monitor D. speciosa (Ventura et al., 1996). Cucurbitacin traps also are suitable for monitoring $D$. virgifera virgifera, D. barberi (Shaw et al., 1984; Hesler \& Sutter, 1993; Levine \& Gray, 1994; Whitworth et al., 2002) and D. undecimpunctata howardi Barber (Whitworth et al., 2002). Diabroticites are also attracted to volatile compounds from Cucurbita maxima Duchesne blossoms (Metcalf \& Metcalf, 1992) which rising doses may increase the attraction in a dose-dependent manner. This would be advantageous for mass trapping (Hoffmann et al., 1996) and applies to D. speciosa, which responds to 1,4-dimethoxybenzene as a volatile attractant (Ventura et al., 2000). Yellow baited traps have been used to capture D. speciosa (Ventura et al., 1996; 2000; 2001). However, responses to colors alone were not recorded.

Since refinements in trap characteristics may improve ability to monitor and mass-trap beetles (Hesler \& Sutter, 1993), field experiments were conducted to assess responses of $D$. speciosa to different trap characteristics. We were particularly interested in whether traps would catch both sexes, as this attribute would be especially advantageous to crops where females oviposit. The tests reported in this study evaluated methods of luring insects to traps (color and volatile attractant), design of volatile attractant dispenser and trap entry ports, and means of retaining trapped insects (cucurbitacin, insecticide and adhesive).

\section{MATERIAL AND METHODS}

Field experiments were carried out in Londrina (Latitude $23^{\circ} 19^{\prime} \mathrm{S}$, Longitude $51^{\circ} 12^{\prime} \mathrm{W}$ ), in the state of Paraná, Brazil. Common bean, Phaseolus vulgaris L., cv. IAPAR 59, fields (sown on September 09, 2000; March 25, 2001 and May 25, 2001) were used as testing sites due to the natural occurrence of high populations of $D$. speciosa. Traps were placed $20 \mathrm{~cm}$ above the plant canopy and, when colored, were coated with yellow gold Suvinil paint 2450-0103 (BASF S.A., São Bernardo do Campo, São Paulo, Brasil). Plastic cups and bottle sticky traps were externally coated with insect adhesive Tangle Trap (Tangle Foot Co., Grand Rapids, MI, USA). Cucurbitacins were from L. vulgaris powder $(0.28 \%$ cucurbitacin B). The powder was sprayed with carbaryl insecticide [Sevin $480 \mathrm{SC}$ (2.25 per $1000 \mathrm{~mL})$ ] which was then dried in the shade before placement in the traps. Carbaryl insecticide was chosen due to its widespread use and efficacy (Roel \& Zatarin, 1989; Metcalf \& Metcalf, 1992) in cucurbitacin baits and traps for diaboriticites. Traps were baited with the attractant 1,4-dimethoxybenze (200 mg/2 mL acetone) and unless otherwise stated the dispenser used was rubber septum. Traps were placed in the field at $3 \mathrm{PM}$ and insects were removed after 48 hours or at 48 hour intervals during longer tests. Cucurbitacin traps were left in the field for a maximum of 12 days to avoid powder detachment from the plastic (Ventura et al., 1996). Distance between traps was $5 \mathrm{~m}$ within a block, and $10 \mathrm{~m}$ between blocks. Beetles were identified according to species and sex in the laboratory.

\section{Responses to yellow color and cucurbitacins}

Yellow and clear sticky cups $(750 \mathrm{~mL})(\mathrm{n}=10)$ were placed up side down on wooden stakes on October 3, 2000 to assess color responses. To assess responses to cucurbitacin B, Petri dishes ( $8.5 \mathrm{~cm}$ diameter) containing carrot slices were used. Although carrot is not a referred host plant of $D$. speciosa, it has been used successfully for beetle rearing in laboratory as a sole foodstuff (Ventura et al., 2001). Dishes were baited or not with $L$. vulgaris powder and were placed on the ground among crop rows on October 23, 2000. Ten replicates were used.

\section{Effect of type of volatile dispenser}

Yellow cup traps were baited with floral attractant, equipped with four types of dispensers: rubber septum (Aldrich, Milwaukee, USA), dental wick (Companhia Manufatura de Tecidos de Algodão, Cataguazes, MG, Brazil), a starch matrix and a feminine hygiene pad Intimusgel (Kimberly, Eldorado do Sul, RS, Brazil). Four replicates were used. The starch matrix was prepared according to Weissling et al. (1989), except for corn flour source (we used Yoki corn flour, Alimentos Yoki, Cambará, PR.) and placed in a voile bag. Control traps received dental wicks saturated with $2 \mathrm{~mL}$ of acetone $(\mathrm{n}=5)$. Traps were placed upside down on iron stakes. Dispensers were hung by a string from a hole in the bottom of the cup and placed $1 \mathrm{~cm}$ below the traps. Traps were placed in the field on April 8, 2001 and captures were assessed every other day until April 20, 2001.

\section{Design of entry ports}

The trap design successfully used for monitoring D. speciosa and Cerotoma arcuata tingomariana Bechyné on common bean fields (Ventura et al., 1996) was used in a larger size ( 0.06 versus $2.0 \mathrm{~L})$ because increases of absolute captures are related with rising sizes of the traps (Youngman et al., 1996). In addition, these bottles, originally used as soft drink containers can be easily obtained on recycling posts. Perforated bottle traps having about 150 holes (5-mm diameter) per bottle, made with a hot 


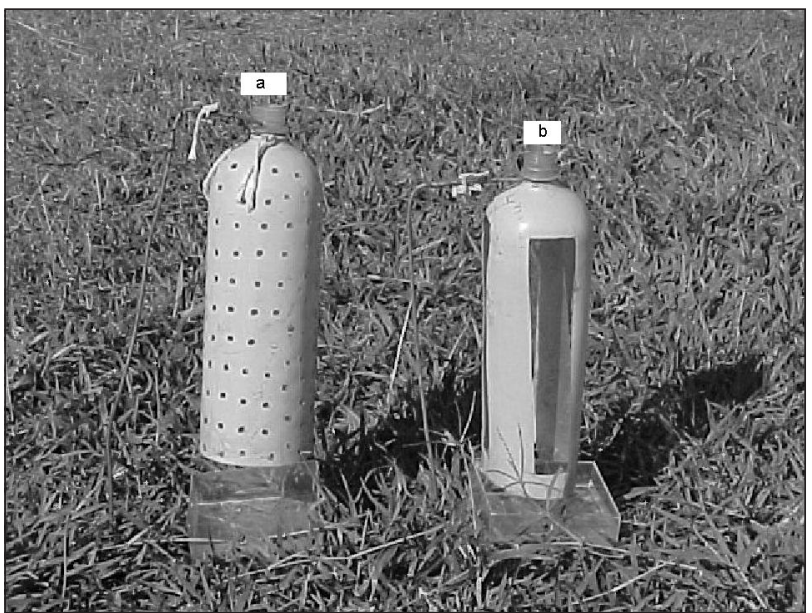

Figure 1 - Perforated (a) and window bottle traps (b) to capture $D$ speciosa.

iron stick (Figure 1a) were compared with window bottle traps having four strips $(3.5 \times 25 \mathrm{~cm})$, symmetrically cut from the bottle surface (Figure 1b). Ten replicates were used. Both trap models were yellow and contained a plastic strip $(3.5 \times 25 \mathrm{~cm})$ treated with $L$. vulgaris powder and insecticide. The bottom of the bottles was removed and acrylic $(12.0 \times 12.0 \times 3.8 \mathrm{~cm})$ vials containing water and detergent were used below the traps to collect dead insects. Rubber septum with floral attractant was placed in the trap. Traps were hung in iron stakes (upside down "L"). The experiment was settled two times, on June 6 and 18, 2001. The tests were left until June 16 and 28,2001 , respectively.

\section{Effect of insecticide}

Perforated bottle trap baited with floral attractant was used to test the effect of insecticide addition on $L$. vulgaris powder. Ten replicates were used. Traps were exposed in the field on June 18, 2001. Samples were collected every other day until June 28, 2001.

\section{Effect of volatile attractant}

Rubber septum with floral attractant in acetone or acetone only were placed in perforated bottle traps to test the effect of volatile attractant. Ten replicates were used. Traps were placed in the field on June 20, 2001. Samples were collected every other day until June 30, 2001.

\section{Comparison of perforated, window and sticky bottle traps}

This test evaluated the relative efficacy of perforated, window, and sticky bottle traps. Seven replicates were used. Sticky traps were made with identical bottle type and color, used for the other traps and did not have the strip with L. vulgaris powder. All traps were baited with floral attractant. Traps were placed in the field on July 6, 2001 and removed 24 hours later due to the high field beetle population (sticky traps could lose efficacy due to excessive adhesion).

\section{Experimental design and statistical analysis}

All experiments were conducted in a randomized complete block design. Data were transformed by $\log$ (x +1 ) constant to normalize the data and reduce heterogeneity of variances. The analysis of variance (ANOVA) was performed followed by Duncan's multiple range test (SAS Institute, 1989) when $\mathrm{F}$ values were significant $(P<0.05)$ and more than two means were compared. Otherwise, paired t-tests were used to analyze data.

\section{RESULTS AND DISCUSSION}

Yellow traps attracted more D. speciosa female and male beetles than did clear traps $[4.3 \pm 0.4$ versus $0.0 \pm 0.0$ and $2.1 \pm 0.5$ versus $0.1 \pm 0.1$, respectively $(\mathrm{t}=$ $6.79, \mathrm{P}=0.000, \mathrm{df}=9$ and $\mathrm{t}=4.47, \mathrm{P}=0.002, \mathrm{df}=9$ respectively)]. No females and few males were captured by clear traps. Saturn yellow was the most attractive color to $D$. virgifera virgifera and $D$. barberi and the color preference ranking was similar for males and females (Hesler \& Sutter, 1993). D. virgifera virgifera was also more attracted to light yellow than to red, blue, dark blue and ultraviolet colors in the laboratory (Ball, 1982). On cucurbits, yellow traps attracted more Acallyma vittatum (F.), and D. virgifera virgifera beetles than did white traps, but capture numbers of Acallyma trivittatum (Mannerheim) and D. undecimpunctata howardi were similar on both trap colors (Hoffmann et al., 1996). Future investigations may determine responses to hue, brightness and saturation of yellow and other colors with similar wavelengths.

Carrot slices baited with $L$. vulgaris powder attracted more males and females than did unbaited slices $(4.3 \pm 0.5$ versus $0.0 \pm 0.0$ and $0.5 \pm 0.5$ versus $0.0 \pm$ 0.0 , respectively) $(\mathrm{t}=7.20, \mathrm{P}=0.000, \mathrm{df}=9$ and $\mathrm{t}=3.00$, $\mathrm{P}=0.015, \mathrm{df}=9$, respectively). Number of captured males was 8.6 times higher than females $(\mathrm{t}=4.34, \mathrm{P}=$ $0.02, \mathrm{df}=9$ ). The higher male population of $D$. speciosa associated with carrot slices treated with $L$. vulgaris supports observations of massive male predominance aggregated on high cucurbitacin content plants (personal observation; Martinez, S. and Avila, C., personal communication for M.U. Ventura). However, field collected males and females showed similar feeding responses to cucurbitacins in laboratory assays (Cintra I. and M.U. Ventura, unpublished). Tallamy \& Halaweish (1993) suggested that the predominance of $D$. barberi and $D$. virgifera virgifera males compared with females captured in cucurbitacins traps in previous studies (Shaw at al., 1984; Fielding \& Ruesink, 1985) is possibly due to male free-ranging mobility rather than sensitivity to cucurbitacins, for their data showed similar responses of males and females with no prior exposure to cucurbitacins (a physiological state that probably more correctly reflects field beetle populations). In addition, unmated $D$. 
undecimpunctata howardi males may prefer to eat cucurbitacins continually to keep its storage until mating occurs (Tallamy \& Halaweish, 1993). Captured insects sex ratio was close to one in the remaining tests (Tables $1,2,3,4$ and 5).

The number of insects when volatile attractant was dispensed on rubber septa differed from unbaited controls (Table 1). Capture numbers on dental wick, starch matrix and feminine hygienic pad dispensers were generally intermediate between those of rubber septa and unbaited traps, and differed from the control only in the 2-4 day period (Table 1). Rubber septa were used in subsequent experiments. Apparently, the starch matrix did not retain satisfactorily the floral attractant. The volatility of the semiochemical and the $\mathrm{pH}$ of the matrix have been implicated as possible factors affecting the retention for several compounds (Weissling et al., 1989).

Higher number of beetles were captured by perforated bottle than window bottle traps ( 1 to 2.4 times more beetles in the first and second experiment) (Table
2). Plastic strips containing L. vulgaris powder lasted longer in perforated bottle traps than in the window ones. Fungal growth was observed in window traps due to rainwater. Window traps apparently allowed greater and faster access of beetles to the feeding stimulant (L. vulgaris powder) although they escaped more easily. The visible surface of the window trap is smaller and probably reduces attraction. Perforated amber plastic medicine vial traps successfully captured and killed $D$. barberi and $D$. virgifera virgifera (Shaw et al., 1984). Perforated cucurbitacin yellow cup traps baited with sex pheromone were used to monitor $D$. undecimpunctata howardi in peanut fields (Herbert Jr. et al., 1996).

Traps with carbaryl insecticide captured about as many beetles than did traps without it, both $2-4$ and 8-10 days after trap placement in the field (1.8 and 2 times more beetles, respectively) (Table 3). A similar trend occurred in the remaining dates $(0-2,4-6$ and 6-8 days), but no differences were detected. Beetle escape difficulty from perforated bottle traps may

Table 1 - Mean number $( \pm \mathrm{SE})$ of adults and sex ratio of $D$. speciosa caught per yellow cup trap baited with 1,4dimethoxybenzene $(200 \mathrm{mg}$ ) in different dispensers in common bean crop (8 to 20 April, 2001).

\begin{tabular}{|c|c|c|c|c|c|c|}
\hline \multirow{2}{*}{ Treatment } & \multicolumn{6}{|c|}{ Days after treatment } \\
\hline & $0-2$ & $2-4$ & $4-6$ & $6-8$ & $8-10$ & $10-12$ \\
\hline $\begin{array}{l}\text { Rubber } \\
\text { septa }\end{array}$ & $9.2( \pm 4.9)^{1}$ a $[1.5]^{2}$ & $20.0( \pm 2.9)$ a $[1.0]$ & $17.9( \pm 1.4)$ a $[0.9]$ & $8.8( \pm 2.8)$ a $[1.0]$ & $8.3( \pm 2.9)$ a $[1.1]$ & $6.0( \pm 0.4)$ a $[0.8]$ \\
\hline $\begin{array}{l}\text { Dental } \\
\text { wick }\end{array}$ & $4.9( \pm 1.7)$ ab $[0.7]$ & $23.8( \pm 2.1)$ a $[0.9]$ & $12.0( \pm 2.6) \mathrm{ab}[1.3]$ & $4.9( \pm 0.7)$ ab $[1.0]$ & $3.9( \pm 2.5)$ ab $[1.1]$ & $3.2( \pm 1.0) \mathrm{ab}[1.2]$ \\
\hline $\begin{array}{l}\text { Starch } \\
\text { matrix }\end{array}$ & $4.8( \pm 2.0)$ ab $[1.1]$ & $18.4( \pm 3.8)$ a $[1.2]$ & $8.7( \pm 2.8)$ ab $[0.7]$ & $4.8( \pm 1.7)$ ab $[1.1]$ & $5.0( \pm 1.1)$ ab $[0.9]$ & $1.2( \pm 0.6) \mathrm{b}[1.1]$ \\
\hline $\begin{array}{l}\text { Menstrual } \\
\text { pad }\end{array}$ & $4.8( \pm 2.5)$ ab $[1.1]$ & $17.7( \pm 2.0)$ a $[1.2]$ & $9.3( \pm 3.1)$ ab $[1.2]$ & $4.8( \pm 0.9)$ ab $[0.9]$ & $2.1( \pm 0.4) b[1.1]$ & $4.0( \pm 1.3)$ ab $[0.8]$ \\
\hline Control & $2.3( \pm 0.9) \mathrm{b}[0.9]$ & $6.2( \pm 0.9) b[1.3]$ & $5.6( \pm 0.8) \mathrm{b}[1.0]$ & $1.9( \pm 1.1)$ b $[1.1]$ & $2.4( \pm 0.7) b[1.2]$ & $1.2( \pm 0.5) \mathrm{b}[0.9]$ \\
\hline $\mathrm{F}$ & $3.3(*)$ & $28.4(* *)$ & $13.1(* *)$ & $3.3(*)$ & $3.9(*)$ & $4.3(*)$ \\
\hline
\end{tabular}

${ }^{1}$ Means in the same column with different letters are different based on Duncan's studentized range test $(P<0.05), \mathrm{n}=4$.

${ }^{2}$ Numbers in blackets refer to sex ratio (females/males).

*Significant at $5 \%$;* Significant at $1 \%$.

Table 2 - Mean number $( \pm \mathrm{SE})$ of adults and sex ratio of $D$. speciosa caught per yellow perforated or window bottle traps baited with $L$. vulgaris powder (sprayed with carbaryl insecticide) and 1,4-dimethoxybenzene $(200 \mathrm{mg})$ in common bean crop (June 6 to 16 and 8 to 18, 2001, respectively).

\begin{tabular}{|c|c|c|c|c|c|}
\hline \multirow{2}{*}{ Trap } & \multicolumn{5}{|c|}{ Days after treatment } \\
\hline & $0-2$ & $2-4$ & $4-6$ & $6-8$ & $8-10$ \\
\hline & \multicolumn{5}{|c|}{ Onset on June 06, 2001 (First experiment) } \\
\hline Perforated & $26.5( \pm 2.1)^{1}$ a $[1.0]^{2}$ & $27.0( \pm 3.0)$ a $[1.2]$ & $45.0( \pm 3.8)$ a $[0.8]$ & $39.5( \pm 3.0)$ a $[0.9]$ & $15.6( \pm 3.1)$ a $[0.9]$ \\
\hline \multirow[t]{2}{*}{ Window } & $13.8( \pm 1.7) \mathrm{b}[0.7]$ & $16.4( \pm 1.6) \mathrm{b}[1.1]$ & $25.5( \pm 2.3) \mathrm{b}[0.9]$ & $38.8( \pm 3.6)$ a $[0.7]$ & $6.5( \pm 1.1) \mathrm{b}[1.3]$ \\
\hline & \multicolumn{5}{|c|}{ Onset on June 18, 2001 (Second experiment) } \\
\hline Perforated & $26.0( \pm 1.8)$ a $[1.1]$ & $29.0( \pm 2.2)$ a $[1.2]$ & $36.3( \pm 1.3)$ a $[1.0]$ & $34.4( \pm 1.9)$ a $[0.9]$ & $26.0( \pm 2.2)$ a $[1.1]$ \\
\hline Window & $23.0( \pm 1.6)$ a $[1.2]$ & $22.5( \pm 1.2) \mathrm{b}[0.9]$ & $16.3( \pm 1.8) \mathrm{b}[1.1]$ & $14.1( \pm 1.6) \mathrm{b}[0.8]$ & $12.0( \pm 1.5) \mathrm{b}[1.2]$ \\
\hline
\end{tabular}

${ }^{1}$ Means in the same column in each date with different letters are different based on paired t- test $(P<0.05), \mathrm{n}=10$.

${ }^{2}$ Numbers in blackets refer to sex ratio (females/males). 
Table 3 - Mean number ( $\pm \mathrm{SE}$ ) of adults and sex ratio of $D$. speciosa caught per perforated yellow bottle traps baited with $L$. vulgaris (sprayed or not with carbaryl insecticide) and 1,4-dimethoxybenzene (200 $\mathrm{mg}$ ) in common bean crop (June 18 to 28,2001 ).

\begin{tabular}{lccccc}
\hline \multirow{2}{*}{ Trap } & \multicolumn{5}{c}{ Days after treatment } \\
\cline { 2 - 6 } & $0-2$ & $2-4$ & $4-6$ & $6-8$ & $8-10$ \\
\hline With Insecticide & $19.2( \pm 3.1)^{1}$ a $[1.2]^{2}$ & $28.0( \pm 1.7)$ a $[0.9]$ & $35.4( \pm 4.1)$ a $[1.3]$ & $41.8( \pm 3.8)$ a $[0.9]$ & $14.3( \pm 1.1)$ a $[0.7]$ \\
Without insecticide & $19.1( \pm 2.3)$ a $[1.3]$ & $15.4( \pm 2.7) \mathrm{b}[1.2]$ & $32.6( \pm 4.8)$ a $[0.8]$ & $37.0( \pm 2.5)$ a $[0.9]$ & $7.2( \pm 3.3) \mathrm{b}[0.7]$ \\
\hline
\end{tabular}

${ }^{1}$ Means in the same column with different letters are different based on paired t-test $(P<0.05), \mathrm{n}=10$.

${ }^{2}$ Numbers in blackets refer to sex ratio (females/males).

Table 4 - Mean number ( \pm SE) of adults and sex ratio of $D$. speciosa caught per yellow perforated bottle traps baited with $L$. vulgaris powder sprayed with carbaryl insecticide and baited or not with 1,4-dimethoxybenzene $(200 \mathrm{mg})$ in common bean crop (June 20 to 30, 2001).

\begin{tabular}{|c|c|c|c|c|c|}
\hline \multirow{2}{*}{ Trap } & \multicolumn{5}{|c|}{ Days after treatment } \\
\hline & $0-2$ & $2-4$ & $4-6$ & $6-8$ & $8-10$ \\
\hline $\begin{array}{l}\text { 1,4-dimethoxy benzene } \\
\text { baited }\end{array}$ & $66.1( \pm 3.84)^{1}$ a $[1.2]^{2}$ & $34.6( \pm 2.98)$ a $[0.9]$ & $17.2( \pm 1.3)$ a $[0.8]$ & $12.0( \pm 1.72)$ a $[0.9]$ & $3.4( \pm 0.73)$ a $[1.3]$ \\
\hline Control (unbaited) & $5.0( \pm 0.57) \mathrm{b}[1.1]$ & $4.2( \pm 0.63) \mathrm{b}[1.3]$ & $1.9( \pm 0.56)$ b $[0.7]$ & $2.9( \pm 0.48)$ b $[0.9]$ & $3.4( \pm 0.73)$ a $[1.3]$ \\
\hline
\end{tabular}

${ }^{1}$ Means in the same column with different letters are different based on paired t-test $(P<0.05), \mathrm{n}=10$.

${ }^{2}$ Numbers in blackets refer to sex ratio (females/males).

have hampered any effect of insecticide treatments (Table 3). Insects also might have been exposed to the insecticide trap, but died outside. In previous studies with other Diabrotica species, cucurbitacin baited traps with Carbaryl insecticide were used, but comparisons between traps with and without insecticide were not reported. Shaw et al. (1984) used 50\% (wt: vol) dilution in water, and Barberchek et al. (1995) $2 \%$, while we used the dose recommended by the manufacturer, $0.23 \%$.

Similar captures of both sexes on traps (Tables 1, 2, 3, 4 and 5) suggest the cucurbitacin trap can be widely used. D. speciosa is a multivoltine beetle which disperses into the crop field from other hosts (Ventura et al., 1996). Traps could be placed on the field edges to prevent infestation thus adhering to the "artificial trap crop" concept (Deem-Dickson \& Metcalf, 1995). Probable applications are trap settlements to avoid damage on leaves and fruits. Female beetles could be intercepted before they attack crops in which their larvae develop on roots (e.g. potato roots). Under these conditions, this management strategy could prove to be cost-effective (Hoffman et al., 1996). Females of $D$. undecimpuctata howardi are reported to be more responsive to cucurbitacins after mating (Tallamy \& Halaweish, 1993).

Traps baited with 1,4-dimethoxybenzene captured more beetles than did the unbaited ones $(13.2,8.2,9.1$, 4.1 and 11.3 times more beetles $0-2,2-4,4-6,6-8$ and $8-$ 10 days, respectively) (Table 4). Differences in $D$. speciosa numbers captured between volatile lure and control traps and controls (Table 4) were similar to those
Table 5 - Mean number $( \pm \mathrm{SE})$ of adults and sex ratio of $D$. speciosa caught per yellow bottle traps of three types baited with $L$. vulgaris powder and 1,4dimethoxybenzene in common bean crop after $24 \mathrm{~h}$ (July 6, 2001) $(\mathrm{n}=10)$.

\begin{tabular}{lc}
\hline Trap type & \\
\hline Perforated & $69.0( \pm 11.35)^{1}[1.3]^{2}$ \\
Window & $74.2(+10.05)[1.1]$ \\
Stick & $78.0(+5.77)[1.1]$ \\
\hline
\end{tabular}

$\mathrm{F}=3.885$ (non-significant.)

${ }^{1}$ Means in the same column with different letters are different based on paired t-test $(P<0.05), \mathrm{n}=10$.

${ }^{2}$ Numbers in blackets refer to sex ratio (females/males).

found in a previous published study with 1,4dimethoxybenzene baited plastic cup traps (9.4 times more beetles) on common bean fields (Ventura et al., 2000).

Similar number of beetles were captured on perforated, window and sticky bottle traps (Table 5). These results clearly define cucurbitacin traps as advantageous due to its simplicity (growers refuse to use traps with sticky traps) (Hesler \& Sutter, 1993; Whitworth et al., 2002). Commercial sticky traps have been compared with cucurbitacin baited vial traps, e.g. the yellow sticky Multigard trap baited with volatile attractants caught more D. virgifera virgifera than did the clear and white cucurbitacin baited traps (Trécé lure trap) (Whitworth et al., 2002). D. virgifera virgifera and $D$. barberi responded differently to several volatile attractants used as bait Pherocon AM, white carton (sticky) and vial (cucurbitacin baited) traps (Lance, 1990). 
Additional studies should emphasize trap features that enhance $D$. speciosa capture (size, color, design and durability; insecticide, volatile attractant and cucurbitacin contents; type of volatile and cucurbitacin dispenser etc.). Trap economic threshold and injury level (monitoring) and the number of traps per area (mass trapping) on several crops, in which the insect is a key pest, must be established besides correlation between beetle trap captures and field populations. These studies are necessary to investigate the potential of plant kairomones traps in the management of $D$. speciosa.

\section{REFERENCES}

BALL, H.J. Spectral responses of the adult western corn rootworm (Coleoptera: Chrysomelidae) to selected wavelengths. Journal of Economic Entomology, v.75, p.932-933, 1982.

CHANDLER, L.D.; FAUST, R.M. Overview of areawide management of insects. Journal of Agricultural Entomology, v.15, p.320-325, 1998.

COSTA, C.P.; JONES, C.M. Cucumber beetle resistance and mite susceptibility controlled by the bitter gene in cucumis sativus L. Science, v.172, p.1145-1146, 1971.

DEEM-DICKSON, L.; METCALF, R.L. Attractants for adult corn rootworm monitoring and control, In: ILLINOIS AGRICULTURAL PESTICIDE CONFERENCE, Urbana, 1995. Proceedings. Urbana, Il.: University of Illinois, 1995. p.93-100.

FIELDING, D.J.; RUESINK, W.G. Varying amounts of bait influences numbers of western and northern corn rootworms (Coleoptera: Chrysomelidae) caught in cucurbitacin traps. Journal of Economic Entomology, v.78, p.1138-1144, 1985.

HERBERT JR., D.A.; ANG, B.N.; HODGES, R.L. Attractants for adult southern corn rootworm (Coleoptera: Chrysomelidae) monitoring in peanut field and relationship of trap catch to pod damage. Journal of Economic Entomology, v.89, p.515-524, 1996.

HESLER, L.S.; SUTTER, G.R. Effect of trap color, volatile attractants and type of toxic bait dispenser on captures of adult corn rootworm beetles (Coleoptera: Chrysomelidae). Environmental Entomology, v.22, p.743750, 1993.

HOFFMANN, M.P.; KIRKWYLAND, J.J.; SMITH, R.F.; LONG, R.F. Field tests with kairomone-baited traps for cucumber beetles and corn rootworms in cucurbits. Environmental Entomology, v.25, p.11721181, 1996.

LANCE, D.R. Factors affecting capture of corn rootworm beetles at traps baited with nonpheromonal attractants. Environmental Entomology, v.19, p.882-889, 1990.
LEVINE, E.; GRAY, M.E. Use of cucurbitacin vial traps to predict corn rootworm (Coleoptera: Chrysomelidae) larval injury in a subsequent crop of corn. Journal of Entomological Science, v.29, p.590-600, 1994.

METCALF, R.L.; METCALF, E.R. Plant kairomones in insect ecology and control. New York: Chapman and Hall, 1992.

ROEL, A.R.; ZATARIM, M. Eficiência de iscas à base de abóbora d‘̣́gua, Lagenaria vulgaris (Curcubitaceae) tratadas com inseticidas, na atratividade a Diabrotica speciosa (Gemar, 1824) ( Coleoptera: Chrysomelidae). Neotropical Entomology, v.18, p.213-219, 1989.

SAS Institute. SAS/STAT. User's Guide. Version 6. 4.ed. Cary: SAS Institute, 1989.

SHAW, J.T.; RUESINK, W.G.; BRIGGS, S.P.; LUCKMANN, W.H. Monitoring populations of corn rootworm beetles (Coleoptera: Chrysomelidae) with a trap baited with cucurbitacins. Journal of Economic Entomology, v.77, p.1495-1499, 1984.

TALLAMY, D.W.; HALAWEISH, F.T. Effects of age, reproductive activity, sex, and prior exposure on sensitivity to cucurbitacins in southern corn rootworm (Coleoptera: Chrysomelidae). Environmental Entomology, v.22, p.925-932, 1993.

VENTURA, M.U.; ITO, M.; MONTALVAN, R. An attractive trap to capture Diabrotica speciosa (Ger.) and Cerotoma arcuata tingomariana Bechyné. Neotropical Entomology, v.25, p.529-535, 1996.

VENTURA, M.U.; MARTINS, M.C.; PASINI, A. Responses of Diabrotica speciosa and Cerotoma arcuata tingomariana (Coleoptera: Chrysomelidade) to volatile attractants. Florida Entomologist, v.83, p.403-410, 2000.

VENTURA, M.U.; MELLO, E.P.; OLIVEIRA, A.R.M.; SIMONELLI, F.; MARQUES, F.A.; ZARBIN, P.H.G. Males are attracted by female traps: a new perspective for management of Diabrotica speciosa (Germar) (Coleoptera: Chrysomelidae) using sexual pheromone. Neotropical Entomology, v.30, p.361-364, 2001.

WEISSLING, T.J.; MEINKE, L.J.; TRIMNELL, D.; GOLDEN, K.L. Behavioral responses of Diabrotica adults to plant-derived semiochemicals encapsulated in a starch borate matrix. Entomologia Experimentalis et Applicata, v.53, p.219-228, 1989.

WHITWORTH, R.J.; WILDE, G.E.; SHUFRAN, R.A.; MILLIKEN, G.A. Comparison of adult corn rootworm (Coleoptera: Chrysomelidae) sampling methods. Journal of Economic Entomology, v.95, p.96-105, 2002.

YOUNGMAN, R.R.; KUHAR, T.P.; MIDGARDEN, D.G. Effect of trap size on efficiency of yellow sticky traps for sampling western corn rootworm (Coleoptera: Chrysomelidae) adults in corn. Journal of Entomological Science, v.31, p.277-285, 1996.

Received January 29, 2004

Accepted April 19, 2005 